\title{
Metabolic Pathway for 2-Keto-L-gulonic Acid Formation in Gluconobacter melanogenus IFO 3293
}

\author{
Tatsuo Hoshino, Teruhide Sugisawa, Masaaki Tazoe, \\ Masako SHINJoH and Akiko FujIwara \\ Department of Applied Microbiology, Nippon Roche Research Center, \\ 200, Kajiwara, Kamakura, Kanagawa 247, Japan \\ Received November 20, 1989
}

\begin{abstract}
The L-sorbosone pathway for 2-keto-L-gulonic acid (2KGA) formation from L-sorbose in Gluconobacter melanogenus IFO 3293 was confirmed. L-Sorbose dehydrogenase, which catalyzes the conversion of $\mathrm{L}$-sorbose to $\mathrm{L}$-sorbosone, was found in the membrane fraction of the microorganism, and L-sorbosone dehydrogenase in the cytosol fraction. The latter enzyme requires NAD or NADP as a cofactor.

2KGA was reduced to L-idonic acid by $2 \mathrm{KGA}$ reductase, but $\mathrm{L}$-idonic acid was re-oxidized to 2KGA by membrane-bound L-idonate dehydrogenase.
\end{abstract}

The metabolic pathway of 2-keto-L-gulonic acid (2KGA) formation from L-sorbose by Pseudomonas putida ATCC 21812 and Gluconobacter melanogenus IFO 3293 proposed by Makover et al. ${ }^{1)}$ includes L-sorbosone as an intermediate of $2 \mathrm{KGA}$ biosynthesis: L-sorbose $\rightleftarrows$ L-sorbosone $\rightarrow 2 \mathrm{KGA}$. They reported the presence of $2 \mathrm{KGA}$ reductase, which catalyzed the conversion of $2 \mathrm{KGA}$ to L-idonic acid, and located L-sorbosone reductase in the cytosol fraction of cell-free extract and L-sorbosone dehydrogenase in the membrane fraction of Gluconobacter melanogenus IFO 3293. Meanwhile, Kitamura et $a l^{2)}$ confirmed the pathway proposed by Makover et al. using a cell-free extract of the same microorganism. However, the detailed characteristics of the enzymes of this pathway have not been described.

We have reported screening for 2KGA high producers using Gluconobacter melanogenus IFO 3293 as a parent strain. ${ }^{3)}$ During the course of the screening, we obtained various metabolic mutants besides $2 \mathrm{KGA}$ high producers. Among them, a 2KGA non-producer, L-idonate accumulator, and L-idonate nonproducer were found. Here, we measured the cellular activity of these mutants by using a resting cell system and measured the enzyme activities in their cytosol and membrane fractions.

\section{Materials and Methods}

Microorganisms. Five mutants derived from Gluconobacter melanogenus SPO- ${ }^{3)}$ were used. The phenotypes of these mutants are shown in Table I. All the strains were maintained on No. 4 agar medium consisting of $0.5 \%$ yeast extract (Difco Laboratories, Detroit, Mich., U.S.A.), $0.5 \%$ glycerol, $0.5 \% \mathrm{MgSO}_{4} \cdot 7 \mathrm{H}_{2} \mathrm{O}$, and $1.2 \%$ agar $(\mathrm{pH} 7.0)$

Chemicals. NAD, NADP, NADH, and NADPH were purchased from Oriental Yeast Industry Co., Ltd. 2,6Dichlorophenolindophenol sodium $\cdot 2 \mathrm{H}_{2} \mathrm{O}$ (DCIP) was purchased from Merck \& Co., Inc. Ca-L-Idonate, L-idose, and L-sorbosone were kindly supplied by Hoffmann-La Roche Inc., Nutley, N.J., U.S.A.

Table I. The Characteristics of the Mutants

\begin{tabular}{lll}
\hline Strain & Parent & \multicolumn{1}{c}{ Characteristics } \\
\hline UV10 & SPO-1 & 2KGA producer \\
E1 & D2 & 2KGA high producer \\
$99-23$ & UV10 & L-Idonate accumulator \\
$101-25$ & UV10 & L-Idonate non-producer \\
C20 & SPO-1 & 2KGA non-producer \\
\hline
\end{tabular}


Analyses. Cell growth was monitored by measuring the optical density at $550 \mathrm{~nm}$ after dissolving the remaining $\mathrm{CaCO}_{3}$ in the fermentation broth with the addition of $0.1 \mathrm{~N}$ hydrochloric acid. Analyses of the product and the substrate were made with TLC, HPLC, and GC by the procedures described previously. ${ }^{3)}$

Jar fermentation. Three- and five-liter jar fermentors were used to cultivate the mutants. The agar plate culture of strain El, C20, or 99-23 was inoculated into $5 \mathrm{ml}$ of medium No. 5 containing $8.0 \%$ L-sorbose, $0.05 \%$ glycerol, $1.5 \%$ yeast extract (Oriental Yeast Industry Co., Ltd.), $0.25 \% \mathrm{MgSO}_{4} \cdot 7 \mathrm{H}_{2} \mathrm{O}$, and $1.5 \% \mathrm{CaCO}_{3}$ in a test tube and cultivated at $30^{\circ} \mathrm{C}$ for 2 days. One $\mathrm{ml}$ of this culture was transferred to $50 \mathrm{ml}$ of the same medium in a $500-\mathrm{ml}$ Erlenmeyer flask and cultivated at $30^{\circ} \mathrm{C}$ for 2 days on a rotary shaker. The medium No. 3B-D containing $7.0 \% \mathrm{~L}-$ sorbose, $0.05 \%$ glycerol, $0.75 \%$ yeast extract (Difco Laboratories), $0.25 \% \mathrm{MgSO}_{4} \cdot 7 \mathrm{H}_{2} \mathrm{O}$, and $1.0 \% \mathrm{CaCO}_{3}$ was used for the strains UV10 and 101-25. The culture thus prepared was used as an inoculum for a jar fermentor containing medium No. 5 and No.3B-D, respectively. Jar fermentors were operated under the conditions given below:

3-1 jar fermentor 5-1 jar fermentor

$\begin{array}{lll}\text { Working volume } & 21 & 31 \\ \text { Agitation speed } & 500 \mathrm{rpm} & 300 \mathrm{rpm} \\ \text { Aeration rate } & 0.75 \mathrm{vvm} & 1.0 \mathrm{vvm} \\ \text { Temperature } & 30^{\circ} \mathrm{C} & 30^{\circ} \mathrm{C} \\ \text { Inoculation } & 2 \% & 2 \% \\ \text { Medium } & \text { No. } 5 & \text { No. 3B-D } \\ \text { Cultivated mutants } & \text { E9, C20,99-23 } & \text { UV10, 101-25 }\end{array}$

After 41.5 to $65.5 \mathrm{hr}$ of fermentation, the culture was harvested. The broth was centrifuged at $300 \mathrm{rpm}$ for $5 \mathrm{~min}$ to remove calcium carbonate from the broth and at 8,000 $\mathrm{rpm}$ the cells were pelleted. After the cell cake was washed with $0.85 \% \mathrm{NaCl}$, the cells were frozen at $-20^{\circ} \mathrm{C}$ until ready for use.

Resting cell system. For the analyses of $2 \mathrm{KGA}$ formation from L-sorbose, L-sorbosone, and L-idonate in a resting cell system, cells of strain El, UV10, 99-23, and C20 harvested at $41.5 \mathrm{hr}$ and strain 101-25 harvested at $65.5 \mathrm{hr}$ were used. Six and a half $\mathrm{ml}$ each of the culture broth was centrifuged at 7,000 rpm, washed twice with deionized water, and suspended in $5 \mathrm{ml}$ of $0.31 \% \mathrm{NaCl}$ solution in a test tube. One half $\mathrm{ml}$ of the substrate solution ( $30 \% \mathrm{~L}$-sorbose or L-sorbosone or $20 \%$ L-idonate) and $4.5 \mathrm{ml}$ of the cell suspension were mixed and incubated at $30^{\circ} \mathrm{C}$ for 1 or 3 days on a test tube shaker. Cells were removed from the mixture by centrifugation after the reaction had been stopped. The amount of $2 \mathrm{KGA}$, Lsorbose, and L-sorbosone in the supernatant of the re- action mixture was measured by HPLC. L-Idonate was analyzed by GC.

Preparation of cytosol and membrane fraction. Cytosol and membrane fractions were prepared in the following manner. The frozen cells (20 grams wet weight) were thawed and suspended in $10 \mathrm{~mm}$ potassium phosphate buffer $(\mathrm{pH} \mathrm{7.0)}$ to $50 \mathrm{ml}$. The cell suspension in the presence of glass beads $(0.1 \mathrm{~mm}$ diameter $)$ was homogenized by a Dyno Mill homogenizer (Willy, A. Bachofen Co., Swiss) at $2,000 \mathrm{rpm}$ for $4 \mathrm{~min}$ at $4{ }^{\circ} \mathrm{C}$. The homogenate thus prepared was kept standing in a beaker at $4^{\circ} \mathrm{C}$ for $10 \mathrm{~min}$ and decanted to recover the supernatant. The glass beads were washed with $25 \mathrm{ml}$ of the buffer and the supernatant was recovered and combined.

The supernatant thus obtained was centrifuged at $1,800 \times g$ for $10 \mathrm{~min}$ to remove the cell debris, and then centrifuged at $100,000 \times g$ for $60 \mathrm{~min}$. The resulting supernatant (about $70 \mathrm{ml}$ ) and the precipitate are referred to here as the cytosol and membrane fractions, respectively. The membrane fraction was suspended in $35 \mathrm{ml}$ of $10 \mathrm{~mm}$ potassium phosphate buffer ( $\mathrm{pH} 7.0$ ) and used for assays.

\section{Enzyme assay.}

1) Cytosol enzymes. Enzyme activity was measured by reading the change of the absorbance of reduced NAD(P) at $340 \mathrm{~nm}$. The complete reaction mixture $(0.41 \mathrm{ml})$ contained $1.0 \mathrm{mg}$ of a substrate, $0.2 \mathrm{mg}$ of NAD, NADP, $\mathrm{NADH}$, or NADPH in $50 \mathrm{~mm}$ potassium phosphate buffer $(\mathrm{pH} \mathrm{7.0)}$, and the cytosol fraction. The reaction was started by the addition of the cytosol fraction and the change of the absorbance at $340 \mathrm{~nm}$ was followed at $30^{\circ} \mathrm{C}$ with a Kontron spectrophotometer (UVIKON 810). One unit of enzyme activity was defined as the amount of enzyme catalyzing the formation of $1 \mu \mathrm{mol}$ of $\mathrm{NAD}(\mathrm{P})$ or NAD(P)H per minute at $30^{\circ} \mathrm{C}$.

2) Membrane-bound enzymes. The enzyme assay was done at room temperature by measuring the decrease in the absorbance of DCIP at $600 \mathrm{~nm}$ with a spectrophotometer. One unit of enzyme activity was defined as the amount of enzyme which catalyzed the reduction of $1 \mu \mathrm{mol}$ of DCIP per minute. The extinction coefficient of DCIP at pH 7.0 was taken as $9.45 \mathrm{~mm}^{-1}$. The basal reaction mixture consisted of $3 \mathrm{ml}$ of $0.1 \mathrm{M}$ potassium

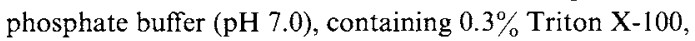
$0.45 \mathrm{ml}$ of $2.5 \mathrm{~mm} \mathrm{DCIP}$, and $4.95 \mathrm{ml}$ of water. This was prepared just before the assay. A cuvette with a 1-cm light path contained $0.4 \mathrm{ml}$ of basal mixture, $5-100 \mu \mathrm{l}$ of $1 \mathrm{M}$ substrate, enzyme solution, and water in a final volume of $0.51 \mathrm{ml}$. A reference cuvette contained all components except the substrate. Enzyme activity was measured as the initial reduction rate of DCIP.

\section{Results}

\section{Preparation of cells}

The cell used for the resting cell system and 
Table II. Analytical Data on the Culture Broth of the Mutants

\begin{tabular}{lcccccc}
\hline Strain & $\begin{array}{c}\text { Cultivation time } \\
(\mathrm{hr})\end{array}$ & OD $_{550}$ & $\mathrm{pH}$ & $\begin{array}{c}\text { 2KGA } \\
(\mathrm{g} / \mathrm{l})\end{array}$ & $\begin{array}{c}\text { L-Idonate } \\
(\mathrm{g} / \mathrm{l})\end{array}$ & $\begin{array}{c}\text { Cells recovered } \\
\text { (wet weight, g) }\end{array}$ \\
\hline UV10 & 41.5 & 24.2 & 5.49 & 4.94 & 16.6 & 58.6 \\
E1 & 41.5 & 35.9 & 5.54 & 17.14 & 14.0 & 45.8 \\
$99-23$ & 41.5 & 33.2 & 5.37 & 4.40 & 26.7 & 40.0 \\
$101-25$ & 65.5 & 12.4 & 5.34 & 16.9 & 1.6 & 21.0 \\
C20 & 41.5 & 28.8 & 5.38 & 0 & 0 & 31.4 \\
\hline
\end{tabular}

Table III. Identification on the Products from Several Substrates by a Resting Cell System

\begin{tabular}{|c|c|c|c|c|c|c|}
\hline Substrate & Product & UV 10 & $\mathrm{E} 1$ & $99-23$ & $101-25$ & $\mathrm{C} 20$ \\
\hline \multirow[t]{2}{*}{ L-Sorbose } & $2 \mathrm{KGA}$ & + & + & + & + & - \\
\hline & L-Idonate & + & + & + & - & - \\
\hline \multirow[t]{2}{*}{ L-Sorbosone } & $2 \mathrm{KGA}$ & + & + & + & + & + \\
\hline & L-Idonate & + & + & + & - & + \\
\hline L-Idonate & $2 \mathrm{KGA}$ & + & + & - & + & + \\
\hline
\end{tabular}

+ , produced: - , not produced.

enzymatic analyses were prepared by using 3or 5-1 jar fermentation as described in Materials and Methods. The analytical data on the culture broth are summarized in Table II. Because the growth of strain 101-25 was slower than the other strains, this culture was harvested after $65.5 \mathrm{hr}$. For the strain 101-25, the recovered cell mass was much less compared with all the others. Because the fermentation was stopped during the $2 \mathrm{KGA}$ production phase, the amount of $2 \mathrm{KGA}$ produced at the time of harvest did not reflect the complete $2 \mathrm{KGA}$ productivity of the mutants. It is assumed that all the strains were harvested in the middle logarithmic phase of their growth.

\section{Resting cell system}

We used a resting cell system to examine the cellular activity for $2 \mathrm{KGA}$ formation using Lsorbose, L-sorbosone, and L-idonate as substrates by the procedure described in Materials and Methods. As shown in Table III, all the strains except for $\mathrm{C} 20$ produced $2 \mathrm{KGA}$ from L-sorbose and strain 101-25 did not accumulate L-idonate from L-sorbose or Lsorbosone. All the strains produced 2KGA
Table IV. Comparison of 2KGA Productivity of a Resting Cell System of the Mutants at the Same Concentration of Cells

\begin{tabular}{|c|c|c|c|c|c|c|}
\hline \multirow{3}{*}{$\begin{array}{r}\text { Strain } \\
\text { Day }\end{array}$} & \multicolumn{6}{|c|}{ Substrate } \\
\hline & \multicolumn{2}{|c|}{ L-Sorbose } & \multicolumn{2}{|c|}{ L-Sorbosone } & \multicolumn{2}{|c|}{ L-Idonate } \\
\hline & 1 & 3 & 1 & 3 & 1 & 3 \\
\hline UV10 & $3.4^{a}$ & 7.9 & 5.3 & 7.2 & 1.4 & 2.5 \\
\hline E1 & 9.2 & 27.1 & 6.3 & 11.0 & 7.4 & 11.9 \\
\hline $99-23$ & 5.7 & 11.6 & 6.4 & 9.7 & 0 & 0 \\
\hline $101-25$ & 23.8 & 46.4 & 13.8 & 22.7 & trace & 2.4 \\
\hline $\mathrm{C} 20$ & 0 & 0 & 3.4 & 6.9 & 1.5 & 2.6 \\
\hline
\end{tabular}

The cell concentration was adjusted at 30.0 at $\mathrm{OD}_{550} \mathrm{~nm}$.

a 2-KGA (grams per liter).

from L-sorbosone. Strain 99-23 did not produce $2 \mathrm{KGA}$ from $\mathrm{L}$-idonate, while the other strains did. It should be noted that strain 99-23 which was selected as a L-idonate accumulator is deficient in the conversion of L-idonate to $2 \mathrm{KGA}$.

2KGA productivity of the mutants at the same cellular concentrations was compared. The results are shown in Table IV. Among them, strain 101-25 had the highest 2KGA 
productivity per cell from L-sorbose and Lsorbosone. The E1 strain produced the largest amount of $2 \mathrm{KGA}$ from L-idonate.

Table V. Protein Concentration of the Cytosol Fraction

\begin{tabular}{lc}
\hline Strain & Protein concentration $(\mathrm{mg} / \mathrm{ml})$ \\
\hline UV10 & 44.3 \\
El & 42.9 \\
$99-23$ & 43.2 \\
$101-25$ & 44.7 \\
C20 & 51.0 \\
\hline
\end{tabular}

Enzymatic study

1) Cytosol enzymes. At the protein concentrations of each cytosol listed in Table V, we measured various enzyme activities. As shown in Table VI, all the strains had rather high NADH oxidase activity. Therefore, when we calculated the enzyme activity when $\mathrm{NADH}$ was the cofactor, we subtracted the NADH oxidase activity from the apparent activity.

We suggest the presence of NADPHdependent L-sorbose reductase, NAD and/ or NADP-dependent L-sorbosone dehydrog-

Table VI. Enzyme ACtivities in the Cytosol Fraction

\begin{tabular}{|c|c|c|c|c|c|c|c|c|c|}
\hline \multirow{3}{*}{$\begin{array}{l}\text { Mutant } \\
\text { Cofactor }\end{array}$} & \multicolumn{9}{|c|}{ Substrate } \\
\hline & \multicolumn{2}{|c|}{ L-Sorbose } & \multicolumn{3}{|c|}{ L-Sorbosone } & \multicolumn{2}{|c|}{$\begin{array}{l}\text { 2-Keto-L-gulonic } \\
\text { acid }\end{array}$} & \multicolumn{2}{|c|}{ None } \\
\hline & $\mathrm{NADH}$ & NADPH & NAD & NADP & NADPH & $\mathrm{NADH}$ & NADPH & NADH & NADPH \\
\hline UV10 & $\begin{array}{c}5.6 \\
(100)\end{array}$ & $\begin{array}{l}22.1 \\
(100)\end{array}$ & $\begin{array}{l}14.7 \\
(100)\end{array}$ & $\begin{array}{c}9.3 \\
(100)\end{array}$ & $\begin{array}{l}20.3 \\
(100)\end{array}$ & $\begin{array}{l}18.5 \\
(100)\end{array}$ & $\begin{array}{l}69.8 \\
(100)\end{array}$ & $\begin{array}{l}11.1 \\
(100)\end{array}$ & $\begin{array}{c}1.8 \\
(100)\end{array}$ \\
\hline $\mathrm{E} 1$ & $(0)$ & $\begin{array}{l}21.0 \\
(95)\end{array}$ & $\begin{array}{l}49.2 \\
(335)\end{array}$ & $\begin{array}{l}22.8 \\
(245)\end{array}$ & $\begin{array}{l}11.4 \\
(56)\end{array}$ & $\begin{array}{l}11.4 \\
(62)\end{array}$ & $\begin{array}{l}94.6 \\
(136)\end{array}$ & $\begin{array}{l}15.4 \\
(139)\end{array}$ & $\begin{array}{c}1.9 \\
(106)\end{array}$ \\
\hline $99-23$ & $\begin{array}{c}3.7 \\
(66)\end{array}$ & $\begin{array}{l}15.3 \\
(69)\end{array}$ & $\begin{array}{l}41.4 \\
(282)\end{array}$ & $\begin{array}{l}17.1 \\
(184)\end{array}$ & $\begin{array}{c}9.5 \\
(47)\end{array}$ & $\begin{array}{c}5.8 \\
(31)\end{array}$ & $\begin{array}{l}71.5 \\
(102)\end{array}$ & $\begin{array}{l}11.3 \\
(102)\end{array}$ & $\begin{array}{c}1.9 \\
(106)\end{array}$ \\
\hline $101-25$ & $\begin{array}{c}3.6 \\
(64)\end{array}$ & $\begin{array}{l}14.8 \\
(67)\end{array}$ & $\begin{array}{l}61.7 \\
(420)\end{array}$ & $\begin{array}{l}29.3 \\
(315)\end{array}$ & $\begin{array}{l}16.6 \\
(82)\end{array}$ & $\begin{array}{l}0 \\
(\quad 0)\end{array}$ & $\begin{array}{c}7.2 \\
(10)\end{array}$ & $\begin{array}{l}29.3 \\
(264)\end{array}$ & $\begin{array}{c}3.6 \\
(200)\end{array}$ \\
\hline $\mathrm{C} 20$ & $\begin{array}{l}3.1 \\
(55)\end{array}$ & $\begin{array}{l}24.1 \\
(109)\end{array}$ & $\begin{array}{l}31.8 \\
(216)\end{array}$ & $\begin{array}{l}17.6 \\
(189)\end{array}$ & $\begin{array}{l}30.6 \\
(151)\end{array}$ & $\begin{array}{c}8.0 \\
(43)\end{array}$ & $\begin{array}{r}111.4 \\
(160)\end{array}$ & $\begin{array}{l}21.0 \\
(189)\end{array}$ & $\begin{array}{c}3.1 \\
(172)\end{array}$ \\
\hline
\end{tabular}

Enzyme activity: $m$ Unit/mg protein. Relative activity is shown in the parenthesis.

Table VII. Conversion Products of Several Substances by the Cytosol Fraction

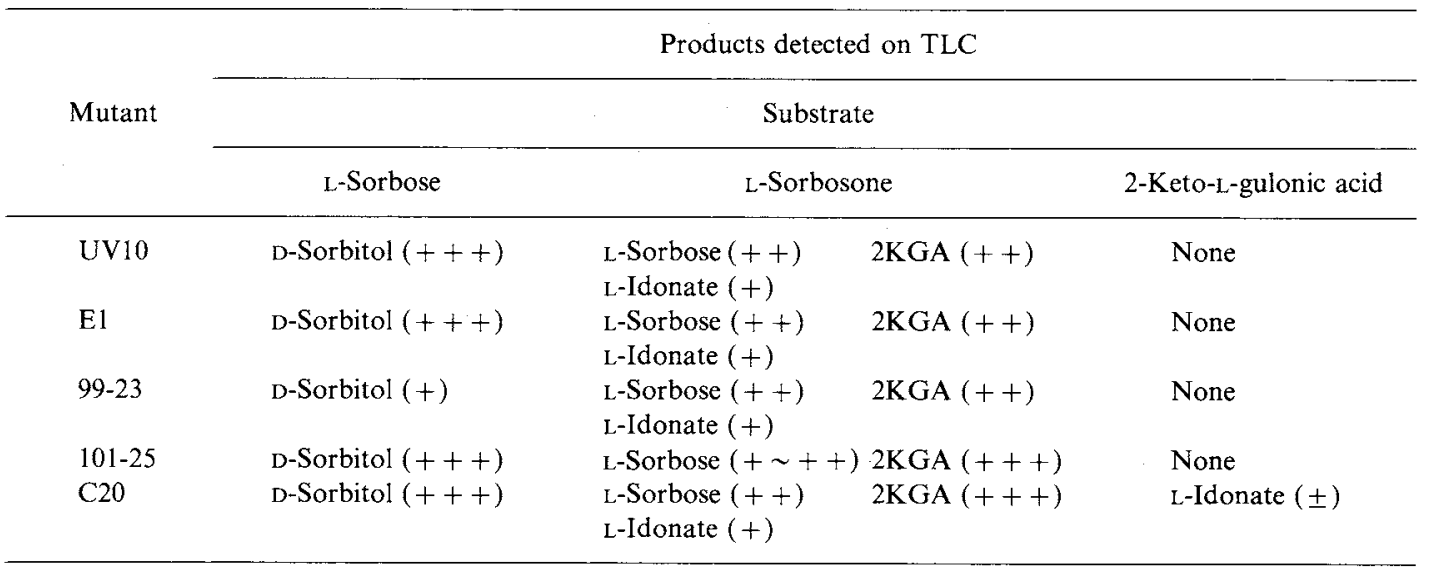

$+\sim+++:$ The quantity of the product is figured. 
enase, NADPH-dependent L-sorbosone reductase, and NADPH-dependent $2 \mathrm{KGA}$ reductase in the cytosol fraction of Gluconobacter melanogenus IFO 3293. In fact, we have already isolated two of these enzymes, $\mathrm{L}$-sorbose reductase and $\mathrm{L}$-sorbosone dehydrogenase and strongly suggest that Lsorbosone dehydrogenase found in the cytosol fraction is predominantly active in the conversion of $\mathrm{L}$-sorbosone to $2 \mathrm{KGA}$, because the membrane-bound L-sorbosone dehydrogenase was less active in this microorganism, as described later. Strain E1, a $2 \mathrm{KGA}$ high producer, had about three-fold higher L-sorbosone dehydrogenase activity than strain UV10 had.

Strain 101-25, which is a L-idonate nonproducer, has little or almost no $2 \mathrm{KGA}$ reductase activity. This means that L-idonate is mainly produced from $2 \mathrm{KGA}$. All strains except for 101-25 had very high $2 \mathrm{KGA}$ reductase activity, which was stronger than L-sorbosone dehydrogenase activity. It is likely that $2 \mathrm{KGA}$ formed in the cytosol immediately can be converted to L-idonate by the reductase reaction, if the NADPH concentration is high enough.
Using TLC analysis, we simultaneously checked the conversion of the products of several compounds in the cytosol fraction in the absence of exogenous cofactor. The results are shown in Table VII. The reduction of $2 \mathrm{KGA}$ to $\mathrm{L}$-idonate was done when $\mathrm{L}^{-}$ sorbosone was a substrate. Nevertheless, Lidonate was formed from $2 \mathrm{KGA}$ when exogenous NADPH was added to the reaction mixture (data not shown). We suggest that NADP in the cytosol was present in its oxidative form, and NADPH was formed in accordance with $\mathrm{L}$-sorbosone oxidation to $2 \mathrm{KGA}$ and could sequentially serve the $2 \mathrm{KGA}$ reduction. Formation of D-sorbitol from Lsorbose, and of L-sorbose from L-sorbosone was observed in all the cases tested.

2) Membrane-bound enzymes. Various substrates were reacted with the crude membranebound enzyme preparation for $4 \mathrm{hr}$ at $30^{\circ} \mathrm{C}$ in the presence of phenazine methosulfate as an artificial electron acceptor. Products were analyzed on TLC and HPLC. The results are shown in Table VIII. 2KGA formation was commonly detected from L-sorbose, L-idonate, L-idose, and D-sorbitol by all the strains except for strains C20 and 99-23. Strains C20 and 99-

Table Vili. Reaction Products by Membrane-bound Enzyme

\begin{tabular}{|c|c|c|c|c|c|c|}
\hline \multirow{2}{*}{ Mutant } & \multicolumn{6}{|c|}{ Substrate } \\
\hline & D-Sorbitol & L-Sorbose & L-Sorbosone & $2 \mathrm{KGA}$ & L-Idonate & L-Idose \\
\hline UV10 & $\begin{array}{l}\mathrm{L}-\text { Sorbose }(t++) \\
\mathrm{L}-\text { Sorbosone }(+) \\
2 \mathrm{KGA}(t)\end{array}$ & $\begin{array}{l}\text { L-Sorbosone }(+) \\
2 \mathrm{KGA}( \pm)\end{array}$ & $2 \mathrm{KGA}(+)$ & None & $2 \mathrm{KGA}(+++)$ & $2 \mathrm{KGA}(+)$ \\
\hline $\mathrm{E} 1$ & $\begin{array}{l}\text { L-Sorbose }(+t+) \\
\text { L-Sorbosone }(+) \\
2 \mathrm{KGA}(+)\end{array}$ & $\begin{array}{l}\text { L-Sorbosone }(+) \\
\text { 2KGA }(+)\end{array}$ & $2 \operatorname{KGA}(+)$ & None & $2 \mathrm{KGA}(+++)$ & $2 \mathrm{KGA}(+)$ \\
\hline $99-23$ & $\begin{array}{l}\text { L-Sorbose }(t+t) \\
\text { L-Sorbosone }(t) \\
2 \mathrm{KGA}(+)\end{array}$ & $\begin{array}{l}\text { L-Sorbosone }(+) \\
2 \mathrm{KGA}( \pm)\end{array}$ & $2 \mathrm{KGA}(+)$ & None & None & $2 \mathrm{KGA}(+)$ \\
\hline $101-25$ & $\begin{array}{l}\text { L-Sorbose }(+++) \\
\text { L-Sorbosone }(+) \\
2 \mathrm{KGA}(+)\end{array}$ & $\begin{array}{l}\text { L-Sorbosone }(+) \\
\text { 2KGA }( \pm)\end{array}$ & $2 \mathrm{KGA}(+)$ & None & $2 \mathrm{KGA}(+++)$ & $2 \mathrm{KGA}(+)$ \\
\hline $\mathrm{C} 20$ & L-Sorbose $(+++)$ & None & $2 \mathrm{KGA}(+)$ & None & $2 \mathrm{KGA}(+++)$ & $2 \mathrm{KGA}(+)$ \\
\hline
\end{tabular}

$\pm \sim+++$ : The quantity of the product is figured. 
Table IX. Substrate Specificity of Membrane Fraction of the Mutants (DCIP method)

\begin{tabular}{|c|c|c|c|c|c|c|}
\hline \multirow{2}{*}{ Strain } & \multirow{2}{*}{$\begin{array}{l}\text { Protein conc. } \\
\qquad(\mathrm{mg} / \mathrm{ml})\end{array}$} & \multicolumn{5}{|c|}{ Enzyme activity [U/mg-protein] on } \\
\hline & & D-Sorbitol & L-Sorbose & 2KGA & L-Idonate & L-Idose \\
\hline UV10 & 4.4 & $\begin{array}{l}0.074 \\
(100)\end{array}$ & $\begin{array}{c}0.28 \\
(100)\end{array}$ & 0 & $\begin{array}{c}0.62 \\
(100)\end{array}$ & $\begin{array}{l}0.089 \\
(100)\end{array}$ \\
\hline E1 & 4.2 & $\begin{array}{l}0.077 \\
(104)\end{array}$ & $\begin{array}{c}0.42 \\
(150)\end{array}$ & 0 & $\begin{array}{c}1.24 \\
(201)\end{array}$ & $\begin{array}{l}0.091 \\
(102)\end{array}$ \\
\hline $99-23$ & 6.75 & $\begin{array}{l}0.019 \\
(26)\end{array}$ & $\begin{array}{c}0.16 \\
(56)\end{array}$ & 0 & $\begin{array}{l}0 \\
(\quad 0)\end{array}$ & $\begin{array}{r}0.065 \\
(73)\end{array}$ \\
\hline $101-25$ & 7.8 & $\begin{array}{l}0.033 \\
(45)\end{array}$ & $\begin{array}{c}0.21 \\
(74)\end{array}$ & 0 & $\begin{array}{c}0.52 \\
(85)\end{array}$ & $\begin{array}{r}0.049 \\
(55)\end{array}$ \\
\hline $\mathrm{C} 20$ & 7.7 & $\begin{array}{l}0.072 \\
(97)\end{array}$ & $\begin{array}{l}0 \\
(\quad 0)\end{array}$ & 0 & $\begin{array}{c}0.88 \\
(143)\end{array}$ & $\begin{array}{r}0.053 \\
(60)\end{array}$ \\
\hline
\end{tabular}

( ): Relative activity.

23, deficient in L-sorbose dehydrogenase and L-idonate dehydrogenase, respectively, did not convert $\mathrm{L}$-sorbose and L-idonate to $2 \mathrm{KGA}$, respectively. $2 \mathrm{KGA}$ was not metabolized by the membrane-bound enzyme preparation. From these observations, we suggest that $G$. melanogenus IFO 3293 has D-sorbitol dehydrogenase, L-sorbose dehydrogenase, L-sorbosone dehydrogenase, L-idonate dehydrogenase, and L-idose dehydrogenase in its membrane fraction.

Various enzyme activities of the membrane fraction on different substrates were examined by the DCIP method. The results are summarized in Table IX. The enzyme activity of membrane-bound L-sorbosone dehydrogenase could not be measured with the DCIP method because L-sorbosone itself strongly decolorized DCIP in the reaction mixture. The strain E1, a 2KGA high producer, showed about 1.5 times higher L-sorbose dehydrogenase activity than UV10. The high L-idonate dehydrogenase activity of the strain E1 was notable as well. Deficiency of L-sorbose dehydrogenase in the strain $\mathrm{C} 20$ and of L-idonate dehydrogenase in the strain 99-23 was confirmed enzymatically.

3) Comparison of $2 K G A$ productivity from $\mathrm{L}-$ sorbosone using the cytosol and the membrane fractions of the strain El. As described above,
Table $X$. Comparison of 2KGA Productivity FROM L-SORBOSONE USING THE CYTOSOL AND THE MEMBRANE FRACTIONS OF THE STRAIN EI

\begin{tabular}{lcl} 
& \multicolumn{2}{c}{ Product (g/l) } \\
\cline { 2 - 3 } Source & $2 \mathrm{KGA}$ & L-Idonate \\
\hline Cytosol fraction & 1.75 & $\begin{array}{l}1.65 \\
\text { Membrane fraction }\end{array}$ \\
\hline
\end{tabular}

The reaction mixture containing $0.2 \mathrm{ml}$ of $0.5 \mathrm{M}$ potassium phosphate buffer $(\mathrm{pH} 7.0), 0.2 \mathrm{ml}$ of $0.5 \mathrm{M} \mathrm{L}$ sorbosone solution, $1.0 \mathrm{ml}$ of water and $0.4 \mathrm{ml}$ of the cytosol or the membrane fraction was incubated at $30^{\circ} \mathrm{C}$ for $5 \mathrm{hr}$ with shaking. Amounts of $2 \mathrm{KGA}$ and L-idonate were measured by HPLC and GC, respectively.

two types of L-sorbosone dehydrogenases: cytosol and membrane-bound types, are present in G. melanogenus IFO 3293. To compare both enzyme activities for $2 \mathrm{KGA}$ formation from $\mathrm{L}$ sorbosone, a product assay was done because the photometric assay did not work for membrane-bound L-sorbosone dehydrogenase. Concentrations of the cytosol and the membrane fractions used for the assay were adjusted so that their ratio might be nearly the same as that in an intact cell. The results are shown in Table $X$. In the assay using the cytosol fraction, $1.75 \mathrm{~g}$ of $2 \mathrm{KGA}$ per liter and 
$1.65 \mathrm{~g}$ of $\mathrm{L}$-idonate per liter were produced. On the other hand, $0.1 \mathrm{~g}$ of $2 \mathrm{KGA}$ per liter was produced by the membrane fraction. Since Lidonate formed in the cytosol fraction was considered to be derived from $2 \mathrm{KGA}$ through the reductive reaction by $2 \mathrm{KGA}$ reductase, the total amount of $2 \mathrm{KGA}$ formed by the cytosol fraction was roughly calculated to be about $3.4 \mathrm{~g}$ per liter. Consequently, cytosol L-sorbosone dehydrogenase was about 30 times more active than membrane-bound L-sorbosone dehydrogenase.

\section{Discussion}

From the results of enzymatic analyses of the mutants, we conclude that strains $\mathrm{C} 20,99-$ 23, and 101-25 are blocked mutants of Lsorbose dehydrogenase, L-idonate dehydrogenase, and $2 \mathrm{KGA}$ reductase, respectively. Accordingly, strain $\mathrm{C} 20$ is unable to produce $2 \mathrm{KGA}$ from $\mathrm{L}$-sorbose, but is able to produce it from L-sorbosone. Because strain 99-23 does not have L-idonate dehydrogenase, the accumulation of L-idonate was observed in the fermentation broth. Strain 101-25 does not accumulate $\mathrm{L}$-idonate in the culture broth from $\mathrm{L}$-sorbose, and its $2 \mathrm{KGA}$ reductase is blocked. This strongly suggests that $2 \mathrm{KGA}$ is a main precursor of L-idonate in the fermentation process. High $2 \mathrm{KGA}$ reductase activity was found in all the strains except for strain 101-25.

The 2KGA high producer, strain El, had higher L-sorbose dehydrogenase, L-sorbosone dehydrogenase, and L-idonate dehydrogenase activities. This indicated that the improvement in $2 \mathrm{KGA}$ productivity from L-sorbose of this strain was a result of the increase in quantity or the change in quality of the several enzymes concerned, not because of one particular enzyme.

When the enzymatic activity to convert Lsorbose or L-sorbosone to $2 \mathrm{KGA}$ of the strains was compared at the same cell concentration of a resting system, strain 101-25 had the highest conversion activity. It is characteristic for this strain to have high $\mathrm{L}$-sorbosone dehydrogenase activity, but this strain grew so slowly in the production medium and so much L-sorbose remained that the production of 2KGA was not feasible.

In summary, D-sorbitol, L-sorbose, and Lidonate dehydrogenases of Gluconobacter melanogenus IFO 3293 are located in the membrane fraction of the cell and L-sorbosone reductase and $2 \mathrm{KGA}$ reductase are located in the cytosol fraction of the cell. L-Sorbosone dehydrogenase is mainly found in the cytosol fraction. Accordingly, we suggest that the permeation of L-sorbosone, which is generated outside the cell, into the cytosol may be important for the formation of $2 \mathrm{KGA}$. To produce 2KGA continuously from L-sorbose, regeneration of NADH or NADPH might be necessary. L-Sorbose reductase, L-sorbosone reductase, 2KGA reductase, and NAD(P)H oxidase may function for this purpose. L-Idonate formed could be easily converted to $2 \mathrm{KGA}$ again by the membrane-bound L-idonate dehydrogenase.

Kitamura et al. ${ }^{2)}$ reported that $\mathrm{L}$-sorbose and L-sorbosone dehydrogenases of Gluconobacter melanogenus IFO 3293 were mainly located in the membrane fraction. In our ob-

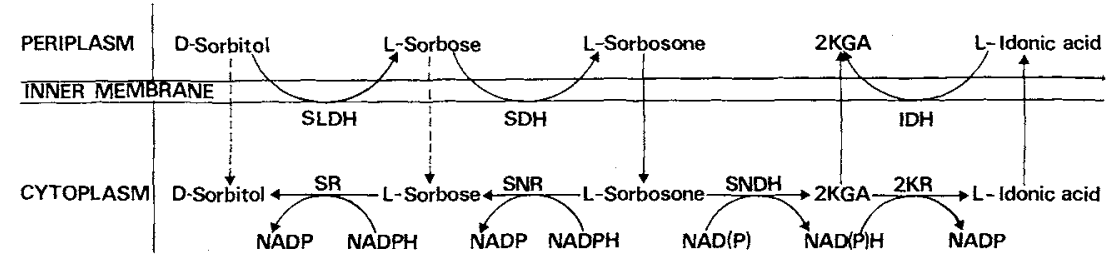

Fig. 1. Proposed Mechanism of 2KGA-relating Pathways of Gluconobacter melanogenus IFO 3293 Abbreviations for enzymes: SLDH, D-sorbitol dehydrogenase; SDH, L-sorbose dehydrogenase; SNDH, Lsorbosone dehydrogenase; IDH, L-idonate dehydrogenase; SR, L-sorbose reductase; SNR, L-sorbosone reductase; $2 \mathrm{KR}, 2$-keto-L-gulonate reductase. 
servation, L-sorbose dehydrogenase is located in the membrane fraction, but L-sorbosone dehydrogenase is mainly located in the cytosol fraction. We consider that membranebound L-sorbosone dehydrogenase must be present to a minor extent.

Based on our observations, we illustrate in Fig. 1 the presumptive metabolic linkage of sugars relating to $2 \mathrm{KGA}$ formation of Gluco- nobacter melanogenus IFO 3293.

\section{References}

1) S. Makover, G. B. Ramsey, F. M. Vane, C. G. Witt and R. B. Wright, Biotech. Bioeng., 17, 1485 (1975).

2) I. Kitamura and D. Perlman, Eur. J. Appl. Microbiol., 2, I (1975).

3) T. Sugisawa, T. Hoshino, S. Masuda, M. Shinjoh, S. Nomura, Y. Setoguchi, M. Tazoe, S. Someha and A. Fujiwara, Agric. Biol. Chem., 54, 1201 (1990). 